\title{
UJI pH DAN FISIS AIR MINUM ISI ULANG DI KECAMATAN TAPUNG KABUPATEN KAMPAR
}

\author{
Sudarto, Sri Fitria Retnowaty, Yulia Fitri, Aji Suroso \\ Program Studi Fisika, Fakultas MIPA dan Kesehatan \\ Universitas Muhammadiyah Riau \\ Email: fitriaridhoni@gmail.com
}

\begin{abstract}
ABSTRAK
Depot Air Minum Isi Ulang (DAMIU) merupakan tempat yang praktis untuk melakukan pengisian air minum. Pada saat ini di Kecamatan Tapung telah banyak berdiri usaha pengisian air minum isi ulang. Sesuai dengan pengamatan yang telah dilakukan di Kecamatan Tapung terdapat 30 DAMIU. Untuk mengetahui karakter fisis dan $\mathrm{pH}$ dari air pada DAMIU tersebut maka perlu dilakukan uji fisis dan $\mathrm{pH}$. Parameter fisis yang diuji yaitu viskositas, massa jenis, Total Padatan Terlarut (TPT), salinitas, konduktivitas listrik, resistivitas, dan Oxidation Reduction Potential (ORP). Hasil pengujian menunjukkan jika hanya terdapat beberapa depot (DAMIU) yang memiliki nilai pH sesuai dengan standar PERMENKES yaitu depot 2, 3, 7 dan 23 dari 30 depot yang diuji. Dan untuk depot lain nilai $\mathrm{pH}$ berada di bawah standar PERMENKES yaitu 6,5 - 8,5 sehingga bersifat asam. Sedangkan untuk hasil dari uji fisis (Massa Jenis dan TDS), seluruh depot memenuhi standar PERMENKES. Sedangkan hasil uji fisis lainnya yaitu viskositas, ORP, Salinitas, Konduktivitas dan Resistivitas memiliki nilai yang sama dengan nilai air yang digunakan sebagai standar (acuan). Dari hasil penelitian secara umum DAMIU di Kecamatan Tapung memiliki karakteristik fisis yang sama dengan sir standar (acuan) dan memenuhi standar PERMENKES.
\end{abstract}

Kata-kunci: DAMIU, pH, uji Fisis.

\section{PENDAHULUAN}

Peningkatan kesehatan masyarakat telah diprogramkan pada Indonesia Sehat 2010. Dengan adanya program ini diharapkan masyarakat akan mempunyai kesadaran, kemampuan, dan kemauan untuk hidup lebih sehat. Untuk meningkatkan kesehatan masyarakat salah satu upaya yang perlu dilakukan adalah pemenuhan kebutuhan air minum yang sehat [1].

Air yang berasal dari sumber-sumber mata air tidak langsung diminum, tetapi harus diolah terlebih dahulu melalui tahap-tahap pengolahan khusus. Pengolahan air menjadi air minum harus mengikuti prosedur yang sudah ditetapkan. Secara sederhana, air sebelum dikonsumsi harus dipanaskan hingga mendidih terlebih dahulu, sehingga mikroorganisme yang terkandung di dalamnya mati [2].

Kualitas air minum yang tidak memenuhi standar dapat mengganggu kesehatan masyarakat, karena dapat membawa penyakit.
Beberapa penyakit yang ditularkan melalui media air yang kurang sehat seperti cacingan, tipus, kolera (muntaber), desentri (BAB berdarah), diare, hepatitis, polio, dan sebagainya [2].

Pada umumnya masyarakat mengkonsumsi air dari sumur dan air yang diolah oleh Perusahaan Daerah Air Minum (PDAM). Dengan kemajuan teknologi dan semakin sibuknya aktivitas masyarakat, maka masyarakat memilih cara yang lebih praktis dan biaya yang lebih murah dalam memenuhi kebutuhan air minum. Salah satu pemenuhan kebutuhan air minum yang menjadi alternatif adalah dengan menggunakan air minum isi ulang. Air minum isi ulang adalah air minum yang diperoleh dari Depot Air Minum Isi Ulang (DAMIU) yang berasal dari sumber air pegunungan yang telah diolah melalui proses chlorinasi, aerasi, filtrasi, penyinaran dengan sinar ultraviolet, dan tidak melalui proses pemanasan [3].

Penelitian tentang DAMIU yang telah dilakukan untuk melihat kandungan 
mikroorganisme, dilakukan oleh Ni Luh Putu Manik Widyanti dan Ni Putu Ristiati, dengan hasil penelitian menunjukkan bahwa ketiga DAMIU di kota Singaraja memenuhi syarat mutu karena tidak ditemukan bakteri koliform. Ariadi Hazmi, dkk juga telah melakukan penelitian tentang DAMIU dengan hasil yaitu, semakin tingginya Oxidation Reduction Potential (ORP) maka waktu yang dibutuhkan bakteri akan semakin pendek hal ini dapat menyebabkan hilangnya mikroorganisme didalam air [3, 4].

Berdasarkan sistem pengolahan dan beberapa penelitian di atas maka dilakukan penelitian untuk mengetahui apakah DAMIU di Kecamatan Tapung memenuhi syarat mutu yang ditetapkan oleh PERMENKES No. 429/MENKES/PER/IV/2010 berdasarkan pH dan karakteristik fisisnya. Cara tersebut yaitu dengan menguji $\mathrm{pH}$ dan fisis berupa parameter viskositas, massa jenis, Total Padatan Terlarut (TPT), salinitas, konduktivitas listrik, resistivitas, dan Oxidation Reductin Potential (ORP).

\section{METODOLOGI PENELITIAN}

\section{Alat}

Alat yang digunakan dalam penelitian ini adalah viscometer Ostwald, TDS meter, Salinity meter, Resistivity meter, Conductivity meter, ORP, meter, pH meter, gelas ukur, Neraca Ohaus, dan stopwatch.

\section{Bahan}

Bahan yang digunakan dalam penelitian ini adalah sampel air isi ulang sebanyak $600 \mathrm{ml}$ untuk setiap DAMIU dari 30 DAMIU dan ditambah $600 \mathrm{ml}$ air standar.

\section{Prosedur Kerja}

Pada penelitian ini, jumlah sampel yaitu sebanyak 30 sampel dari 30 DAMIU dan sampel standar. Depot 1 hingga 15 diambil pada tanggal 27 Maret 2013, dan depot 16 hingga 30 diambil pada tanggal 30 Maret 2013. Kemudian dilakukan uji karakteristik fisis dan $\mathrm{pH}$ pada sampel tersebut. Pada masing-masing pengambilan juga dilakukan pengambilan dan pengujian sampel air standar sebagai pembanding. Gambar 80 menunjukkan prosedur kerja dari penelitian ini.

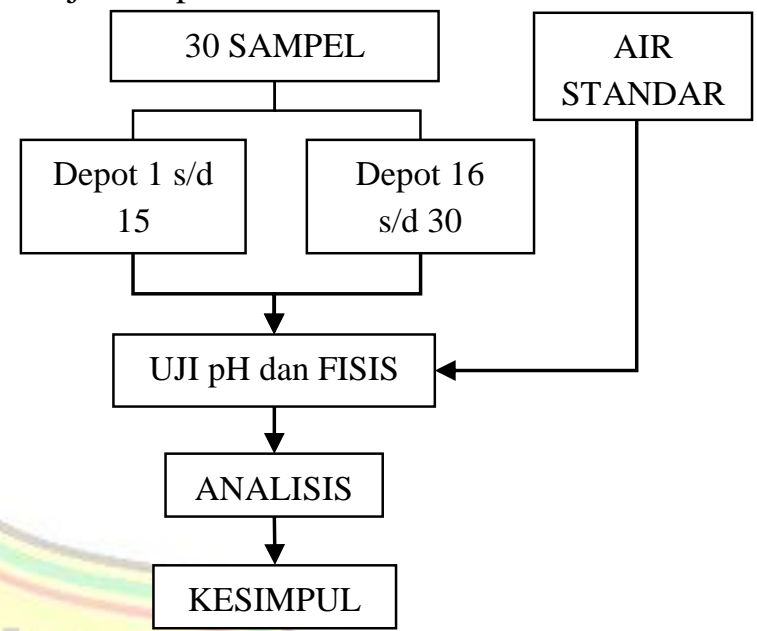

Gambar. 1. Diagram proses penelitian air DAMIU

\section{Uji pH}

Pada uji pH sampel air akan diukur dengan $\mathrm{pH}$ meter yang bekerja berdasarkan prinsip elektrolit/konduktivitas suatu larutan. Sebelum $\mathrm{pH}$ meter digunakan untuk mengukur $\mathrm{pH}$ sampel air, $\mathrm{pH}$ meter terlebih dahulu dikalibrasi dengan menggunakan buffer. Kemudian $\mathrm{pH}$ meter dimasukkan ke dalam air untuk mengetahui nilai $\mathrm{pH}$. Nilai $\mathrm{pH}$ dapat dilihat pada layar yang dihubungkan dengan alat pedeteksi (pembaca) nilai $\mathrm{pH}$. Uji $\mathrm{pH}$ dilakukan pengulangan sebanyak 3 kali untuk mendapatkan nilai yang tepat.

\section{Uji Viskositas}

Alat yang digunakan dalam uji Viskositas adalah viskometer Ostwald. Cara penggunaan viskometer Ostwald yaitu air dipakai sebagai pembanding, pertama air dimasukkan melalui tabung A kemudian dihisap agar masuk ketabung B tepat sampai batas A kemudian dilepaskan dan siapkan stopwatch sebagai pengukur waktu. Jika waktu yang diperlukan air untuk bergerak dari permukaan A sampai $\mathrm{B}$ adalah $T_{1}$, maka percobaan diganti dengan aquadest

Setelah data diperoleh, kemudian dimasukan ke dalam persamaan (2.1) untuk mendapatkan nilai viskositas dari sampel air yang digunakan. Uji viskositas dilakukan sebanyak 3 kali untuk mendapatkan data yang lebih akurat.

$$
\frac{\eta_{1}}{\eta_{2}}=\frac{T_{1}}{T_{2}} \frac{\rho_{1}}{\rho_{2}}
$$


Dengan $\eta_{1}$ adalah viskositas dari sampel air yang ingin diketahui dan $\eta_{2}$ merupakan viskositas aquadest yang digunakan sebagai pembanding. Kemudian $\rho_{1}$ massa jenis air dan $\rho_{2}$ merupakan massa jenis dari aquadest. Dan untuk $T_{1}$ merupakan waktu yang dibutuhkan sampel air untuk melalui kapiler dari viskometer Ostwald dan $T_{2}$ adalah waktu dari aquadest.

\section{Uji Massa Jenis}

Uji massa jenis dilakukan dengan cara memasukkan air kedalam gelas ukur sebanyak 50 ml. Kemudian air ditimbang dengan neraca digital dan dicatat hasilnya. Selanjutnya menentukan massa jenis air tersebut dengan menggunakan persamaan (2.2). Uji massa jenis tersebut diulang sebanyak 3 kali.

$$
\rho=\frac{m}{v}
$$

\section{Uji Total Disolve Solid (TDS)/Total} PadatanTerlarut (TPT)

Untuk uji TDS dilakukan dengan menggunakan alat TDS meter. Caranya yaitu dengan memasang probe dan menekan tombol function pada display menjadi fungsi TDS. Setelah itu masukkan probe ke dalam air untuk melihat nilai TDS. Nilai TDS dapat dilihat pada layar. Pengujian dilakukan sebanyak 3 kali.

\section{Uji Salinitas}

Uji salinitas dilakukan untuk mengetahui kandungan garam yang terlarut di dalamnya. Cara yang dilakukan untuk uji salinitas yaitu dengan menggunakan alat salinity meter. Cara pengujian salinitas yaitu dengan memasukan probe ke dalam air. Kemudian menekan tombol fungsi yang terdapat pada layar menjadi fungsi salinitas. Seletah itu nilai salinitas dapat dilihat pada layar tersebut. Pengujian nilai salinitas diulangi sebanyak 3 kali.

\section{Uji Konduktivitas}

Pada Uji konduktivitas alat yang digunakan adalah conductivity meter. Caranya yaitu dengan memasang probe. Kemudian menekan tombol fungsi pada layar menjadi fungsi konduktivitas. Selanjutnya alat pembaca dimasukkan ke dalam air dan nilai konduktivitas dapat dilihat pada layar tersebut. Uji konduktivitas juga dilakukan pengulangan sebanyak 3 kali.

\section{Uji Resistivitas}

Uji resistivitas dilakukan dengan menggunakan alat resistivity meter. Caranya dengan menghubungkan probe dengan layar yang akan menampilkan nilai resistivitas. Kemudian menekan tombol fungsi pada layar yang telah dihubungkan dengan alat pembaca ke dalam fungsi resistivitas. Kemudian alat pembaca nilai dimasukkan ke dalam air setelah itu nilai dapat dilihat pada layar tersebut. Uji resistivitas juga dilakukan sebanyak 3 kali.

\section{Uji Oxidation Reduction Potential (ORP) \\ Untuk uji ORP dilakukan dengan} menggunakan alat ORP meter. Caranya dengan menghubungkan probe dengan display (layar pembaca nilai ORP). Selanjutnya mengubah fungsi pada layar menjadi fungsi ORP. Kemudian memasukan alat pembaca ke dalam air, dan nilai ORP dapat dilihat pada layar. Uji ORP diulangi sebanyak 3 kali.

\section{HASIL DAN PEMBAHASAN pH}

pH merupakan tingkat keasaman maupun basa suatu cairan (larutan). Gambar 2 menunjukkan nilai $\mathrm{pH}$ air DAMIU yang terletak di wilayah Kecamatan Tapung. Dari hasil tersebut dapat dilihat nilai $\mathrm{pH}$ untuk depot pertama hingga terakhir berbeda-beda.



Gambar. 2. Hasil Penelitian pH DAMIU

Dalam gambar tersebut terlihat jika tidak semua depot memiliki nilai $\mathrm{pH}$ yang sesuai dengan Peraturan Menteri Kesehatan Republik Indonesia No. 429/MENKES/PER/IV/2010 yaitu 6,5-8,5. Dan depot yang memiliki nilai $\mathrm{pH}$ 
memenuhi standar PERMENKES yaitu depot ke2, 3, 7 dan 23. Sedangkan depot yang lain nilainya masih berada di bawah 6,5. Hal ini menunjukkan jika air pada depot lain memiliki tingkat keasaman yang lebih tinggi dari yang distandarkan oleh PERMENKES. Tingkat keasaman $\mathrm{pH}$ dapat disebabkan karena aktivitas lingkungan sekitar, misalnya wilayah pasar, kebun, pemukiman padat, bengkel dan lainnya seperti pembuangan limbah. [19, 20].

Hanya saja dari kondisi tersebut ada beberapa depot yang memiliki wilayah yang berdekatan tetapi dapat memenuhi standar $\mathrm{pH}$ yang telah ditetapkan. Ini mungkin dikarenakan ada perbedaan faktor pengolahan. Selain itu faktor kebersihan tempat penampungan air juga ikut mempengaruhi. Banyaknya mikoroorganisme yang muncul akibat kebersihan tidak terjaga dapat meningkatkan keasaman yang berakibat menurunnya nilai $\mathrm{pH}[19,20]$.

\section{Viskositas}

Gambar 3 menunjukkan Nilai viskositas air DAMIU pada Kecamatan Tapung. Pada depot ke2 hingga depot ke-12 nilai viskositas berada jauh di bawah nilai viskositas air yang dijadikan standar (S) yaitu 1,368 Ns/ $\mathrm{M}^{2}$. Termasuk depot ke-15 yang juga memiliki nilai viskositas berada di bawah nilai air standar (S). Dan depot yang mendekati nilai standar yaitu 1, 9, 17, 18, 20, 23 ddan 24. Sedangkan pada depot 13, 14, 16, 19, 21 dan 22 nilai viskositas lebih tinggi dari viskositas air standar.

Naiknya nilai viskositas dapat disebabkan oleh banyak hal, diantaranya kemurnian dari sebuah cairan itu sendiri. Semakin tinggi kemurnian suatu cairan maka akan semakin rendah nilai dari viskositas cairan tersebut. Sebaliknya jika semakin rendah kemurnian suatu cairan maka akan semakin tinggi nilai viskositas dari cairan itu.

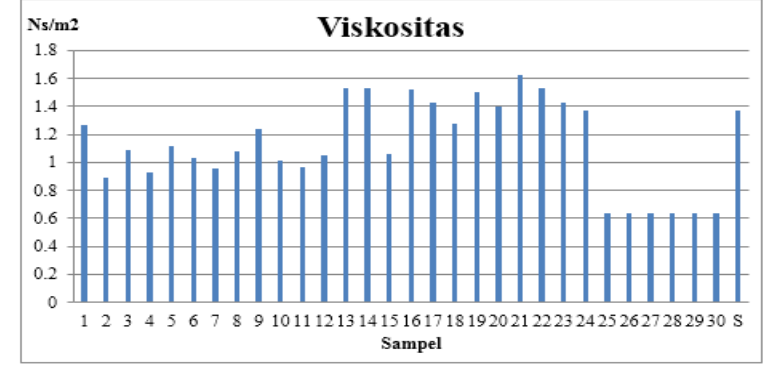

Gambar. 3. Hasil Penelitian Viskositas DAMIU

Salah satu faktor yang menentukan kemurnian dari air isi ulang adalah proses dari penyulingan pada depot tersebut. Jika diperhatikan depot 1 hingga 15 memiliki nilai viskositas yang menurun dibandingkan depot 16 hingga 30. Faktor perbedaan nilai viskositas pada masing-masing DAMIU tersebut dapat disebabkan oleh faktor suhu [11].

Kemudian rendahnya nilai viskositas pada depot 25 hingga 30 dapat disebabkan karena nilai TDS dan salinitas pada depot tersebut juga rendah. Dimana TDS merupakan jumlah total padatan terlarut dalam air yang dapat mempengaruhi nilai viskositas.

Suhu pada saat pengambilan nilai viskositas dapat menyebabkan adanya perbedaan nilai viskositas pada setiap depot. Seperti pada depot 16 hingga 30 , pengambilan nilai viskositas diambil pada hari yang berbeda. Dimana suhu air pada hari pengambilan data tersebut adalah 28$29^{\circ} \mathrm{C}$. Dan pengambilan data pada depot 1 hingga 15 diambil dengan suhu air $30-32^{\circ} \mathrm{C}$. Hal tersebut dikarenakan kekentalan suatu cairan dipengaruhi oleh suhu, jika suhu cairan meningkat maka kekentalan akan menurun dan sebaliknya jika suhu cairan menurun maka kekentalan cairan meningkat [11].

\section{Massa Jenis}

Perbandingan antara massa air dengan volume air disebut dengan massa jenis Gambar 4 menunjukkan hasil data massa jenis dari air DAMIU. 


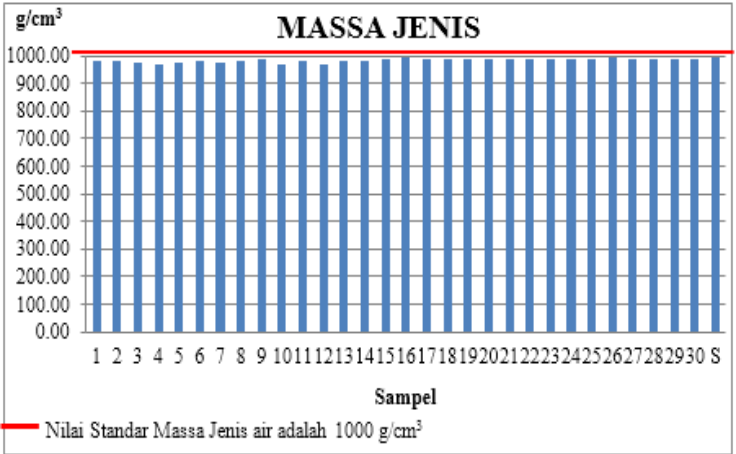

Gambar. 4. Hasil Penelitian Massa Jenis DAMIU

Nilai massa jenis yang didapatkan menunjukkan bahwa pada semua DAMIU memiliki nilai massa jenis yang mendekati dengan nilai standar kualitas air minum PERMENKES yaitu $1000 \mathrm{~g} / \mathrm{cm}^{3}$ [13].

\section{Total Disolve Solid (TDS)}

TDS atau Total Padatan Terlarut (TPT) yaitu unsur total padatan yang terkandung dalam suatu cairan. Gambar 5 menunjukkan nilai TDS pada DAMIU di Kecamatan Tapung. Pada Gambar tersebut hanya terdapat beberapa depot yang memiliki nilai TDS tinggi. Salah satu depot yang memiliki nilai tinggi depot 11 . Depot tersebut berada pada 10 meter dari rumah makan di sebelah utara, sebelah timur rumah warga, sebelah selatan toko harian dan sebelah barat adalah bengkel. Dengan keberadaan tempat disekitarnya tidak menutup kemungkinan banyak zat yang mudah terlarut di dalam air. Sedangkan untuk depot yang lain zat terlarut lebih sedikit dibandingkan dengan DAMIU standar[19, 20].

Selain itu faktor dari pengolahan air pada DAMIU tersebut juga dapat mempengaruhinya. Dimana pada depot 11 menggunakan sistem pengolahan dengan sinar UV (ultraviolet). Kemudian untuk depot 10 dan 12 menggunakan sistem ozonisasi. Dengan sistem pengolahan air yang berbeda pada setiap DAMIU maka akan memberikan perbedaan pada setiap nilai parameter [9].

Nilai TDS pada depot lain masih berada di bawah nilai TDS air yang digunakan sebagai standar acuan (S). Nilai untuk semua depot tersebut yaitu berada pada rentang 4-160 mg/l. Rentang nilai TDS pada semua DAMIU masih masuk ke dalam batasan nilai yang ditetapkan oleh PERMENKES yaitu sebesar $500 \mathrm{mg} / \mathrm{l}$ sebagai batas maksimum. Dengan demikian dilihat dari nilai TDS, maka air pada DAMIU Kecamatan Tapung memenuhi syarat kelayakkan air minum oleh PERMENKES [19].



Gambar. 5. Hasil Penelitian TDS DAMIU

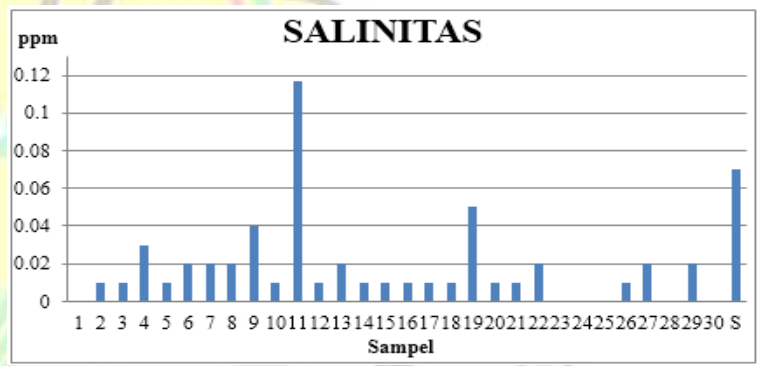

Gambar. 6. Hasil Penelitian Salinitas DAMIU

\section{Salinitas}

Kadar garam suatu cairan atau banyak sedikitnya kandungan garam yang terkandung dalam suatu cairan disebut salinitas. Gambar 6 menunjukkan nilai salinitas yang terkandung dalam air pada DAMIU di Kecamatan Tapung. Dalam gambar tersebut terlihat jika nilai salinitas pada setiap depot berbeda-beda, dan ada beberapa yang mengandung salinitas tinggi. Nilai tertinggi terdapat pada depot 11 dan berada di atas nilai salinitas standar. Terkait dengan nilai TDS pada depot 11, nilai salinitas juga dapat dipengaruhi oleh padatan terlarut, selain itu juga dipengaruhi oleh lokasi depot yang dekat dengan rumah makan, rumah warga, toko harian dan bengkel. Sehingga nilai salinitas pada depot 11 lebih besar dibandingkan dengan depot lainnya.

Kemudian untuk depot lainnya nilai salinitas masih berada di bawah nilai air standar. Maka air pada semua depot kecuali depot 11 masih layak dikonsumsi jika dibandingkan dengan nilai salinitas air standar.

Perbedaan nilai salinitas pada semua depot tidak mempengaruhi kualitas air tersebut. Hal tersebut karena nilai salinitas pada depot tersebut 
masih berada pada rentang yang diperbolehkan yaitu $0,01-0,11 \mathrm{ppm}$ atau $0,01-0,11 \%$. Arti dari nilai tersebut yaitu terdapat $0,01-0,11$ gram air laut yang terkandung dalam 1000 gram air tawar. Dan kisaran untuk air tawar yaitu 0,5 - 5\%, sehingga air masih layak untuk dikonsumsi [14].

\section{Konduktivitas}

Daya hantar listrik yang dimiliki oleh suatu cairan disebut konduktivitas. Gambar 7 merupakan nilai dari konduktivitas air pada DAMIU, dimana konduktivitas merupakan suatu kemampuan cairan dalam menghantarkan listrik. Nilai konduktivitas yang ditunjukkan pada gambar tersebut berbeda-beda untuk setiap depot. Nilai konduktivitas terbesar terdapat pada depot 1 , hal ini merupakan pengaruh dari tingginya jumlah padatan terlarut pada depot tersebut.

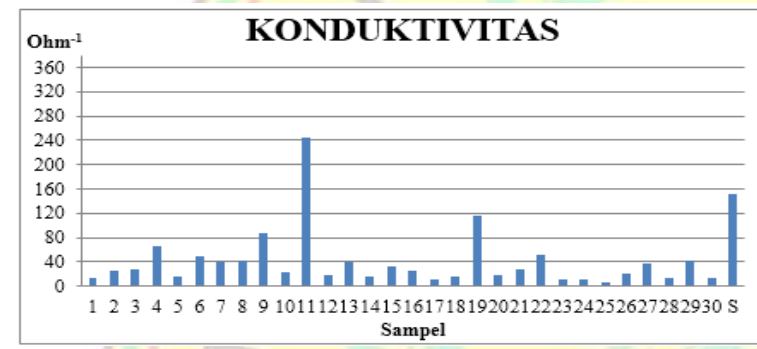

Gambar. 7. Hasil Penelitian Konduktivitas DAMIU

Karena semakin tinggi jumlah padatan terlarut maka akan menyebabkan nilai konduktivitas meningkat. Tinggi rendahnya konduktivitas suatu cairan dapat disebabkan oleh beberapa faktor, diantaranya lokasi tempat DAMIU dan suhu. Depot dengan lokasi disekitar rumah warga sudah banyak aktivitas limbah rumah tangga.

Nilai konduktivitas air DAMIU ditunjukkan pada Gambar 7. Faktor suhu juga dapat berpengaruh, dimana semakin tinggi suhu pada saat pengambilan maka akan semakin tinggi nilai konduktivitas suatu cairan. Sehingga dapat mempengaruhi nilai konduktivitas dari air DAMIU tersebut $[15,19]$.

\section{Resistivitas}

Berbanding terbalik dengan konduktivitas, resistivitas merupakan kemampuan suatu cairan dalam menghambat aliran listrik. Gambar 8 menunjukkan nilai resisitivitas pada air DAMIU di wilyah Kecamatan Tapung.

Resistivitas merupakan kebalikan dari konduktivitas, yaitu kemampuan suatu cairan dalam menghambat ataupun memperlambat aliran listrik. Gambar 82 menunjukkan hasil dari nilai resistivitas DAMIU. Pada Gambar tersebut dapat dilihat jika nilai dari depot ke-1 hingga ke30 memiliki nilai yang berbeda-beda. Sama halnya dengan konduktivitas, nilai resistivitas juga dipengaruhi oleh sistem pengolahan air dan suhu. Perbedaannya yaitu jika suhu meningkat maka nilai resitivitas akan menurun dan sebaliknya [16].

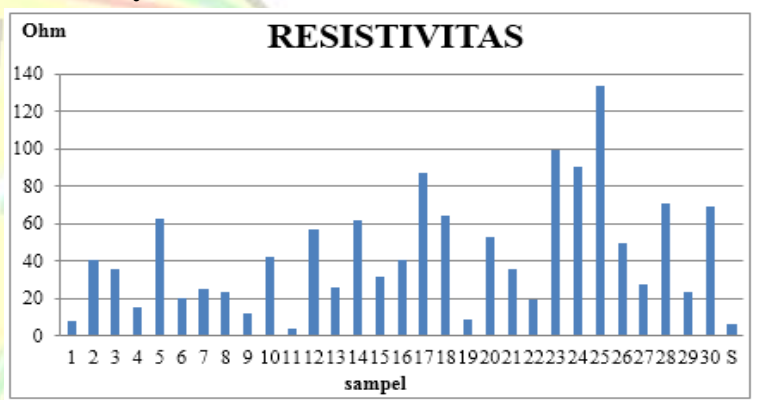

Gambar. 8. Hasil Penelitian Resistivitas DAMIU

Berikut hasil dari nilai resisitivitas yang ditunjukkan pada Gambar 8. Nilai resistivitas yang telah dihasilkan jika dibandingkan dengan nilai konduktivitas, maka sesuai dengan teori yang ada. Dimana dalam teori tersebut menyebutkan jika nilai konduktivitas tinggi, maka nilai resistivitas akan kecil dan begitu juga sebaliknya. Seperti yang dapat dilihat pada depot 11 memiliki nilai resisitivitas rendah sedangkan unutk nilai konduktivitasnya tinggi. Dan untuk nilai resistivitas dan konduktivitas yang dihasilkan pada setiap depot sesuai dengan teori tersebut. Dimana ketika nilai konduktivitas pada DAMIU tinggi maka nilai resisitivitas air pada DAMIU tersebut rendah, dan begitu sebaliknya [16].

\section{ORP (Oxidation Reduction Potential)}

ORP merupakan tingkat kemampuan suatu cairan dalam membunuh bakteri didalam air tersebut. Semakin tinggi nilai ORP maka akan semakin cepat waktu yang dibutuhkan cairan tersebut dalam membunuh bakteri. Oxidation Reduction Potential (ORP) dgunakan untuk 
mengetahui jumlah kandungan mikroorganisme yang terdapat dalam air.

Gambar 9 menunjukkan jika nilai ORP dari depot 1 hingga ke-17 cukup rendah yaitu pada rentang 160-250 Mv. Nilai tersebut cukup jauh jika dibandingkan dengan nilai ORP yang dijadikan sebagai standar (S). Sedangkan untuk nilai ORP pada depot 18 hingga 30 cukup tinggi, yaitu pada rentang 270-366 Mv. Perbedaan nilai tersebut dapat disebabkan oleh proses pengolahan air pada masing-masing DAMIU.

Selain itu adanya pengurasan pada penampungan air disetiap DAMIU juga dapat menjadi salah satu faktor perbedaan nilai ORP tersebut. Faktor lain yang menyebabkan nilai ORP pada depot 18 hingga 30 yaitu karena depot tersebut memiliki lokasi yang cukup sedikit terdapat rumah warga. Dengan lokasi tersebut maka aktivitas limbah rumah tangga juga tidak terlalu banyak, sehingga menyebabkan nilai ORP tinggi.

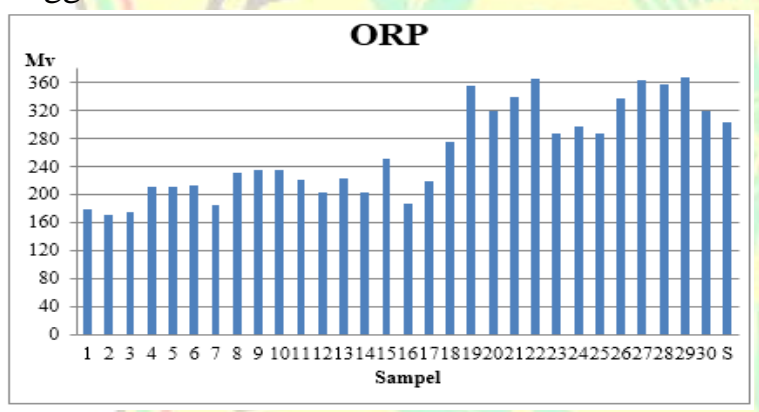

Gambar. 9. Hasil Penelitian ORP DAMIU

Jika semakin tinggi nilai suatu ORP air, maka akan semakin pendek waktu yang diperlukan untuk membunuh bakteri yang terdapat dalam air minum. Dengan demikian DAMIU yang mampu membunuh bakteri dalam air dengan waktu yang pendek yaitu pada depot 18 hingga 30. Hal tersebut karena nilai ORP pada depot tersebut cukup tinggi. Dan pada depot 1 hingga 17 memerlukan waktu yang lebih lama untuk membunuh bakteri. Hal tersebut dikarenakan nilai ORP pada depot tersebut lebih rendah dibandingkan dengan depot 18 hingga 30 $[4,18]$.

\section{KESIMPULAN}

Dari hasil dan pembahasan di atas maka dapat diambil beberapa kesimpulan mengenai Uji
pH dan Fisis Air Minum Isi Ulang di Kecamatan Tapung Kabupaten Kampar, diantaranya.

1. Nilai $\mathrm{pH}$ yang diperoleh dari depot ke $2,3,7$ dan 23 adalah 6,5-6,8. Nilai $\mathrm{pH}$ tersebut memenuhi standar dari Peraturan Menteri Kesehatan Republik Indonesia No. 429/MENKES/PER/IV/2010 yaitu 6,5-8,5 dan air yang digunakan sebagai standar (acuan). Sedangkan pada depot lain memiliki nilai $\mathrm{pH}$ yang lebih kecil, sehingga air dari depot tersebut lebih asam.

2. Nilai TDS pada semua depot masih berada di bawah nilai standar maksimum PERMENKES. Sehingga nilai TDS DAMIU di Kecamatan Tapung masih memenuhi standar kualitas air minum dari PERMENKES.

3. Nilai konduktivitas tertinggi berada pada depot 11. Dapat disebabkan karena depot tersebut memiliki nilai TDS yang tinggi.

4. Dari hasil uji fisis yang termasuk dalam PERMENKES yaitu massa jenis dan TDS, seluruh depot yang berada di wilayah Kecamatan Tapung Kabupaten Kampar memenuhi standar PERMENKES untuk air minum.

5. Hasil uji fisis lainnya yaitu viskositas, ORP, Salinitas, Konduktivitas dan Resistivitas memiliki nilai yang sesuai dengan nilai air yang digunakan sebagai standar (acuan).

6. Dengan hasil yang diperoleh dari semua pengujian maka seluruh DAMIU di Kecamatan Tapung memiliki karakteristik fisis yang memenuhi standar PERMENKES dan air standar (acuan).

\section{DAFTAR PUSTAKA}

Depkes RI, 1999. Rencana Pembangunan Kesehatan Menuju Indonesia Sehat 2010, Jakarta.

Bambang S dan R.Adriyani. Higiene Sanitasi Depot Air Minum Isi Ulang Di Kecamatan Tanjung Redep Kabupaten Berau Kalimantan Timur. Jurnal Kesehatan Lingkungan Vol. 4 No. 2 Januari 2008 Hal. 81-88.

Ni Luh Putu Manik Widiyanti dan Ni Putu Ristiati. Analisa Kualitatif Bakteri 
Koliform Pada Depot Air Minum Isi Ulang

Di Kota Singaraja Bali. Jurusan Pendidikan Biologi, FMIPA IKIP Negeri Singaraja. Bali.

Hazmi A, dkk. Penghilangan Mikroorganisme dalam Air Minum dengan Dielectric Barrier Discharge. Jurnal Rekayasa Elektrika Vol. 10 No.1 April 2012.

Pitoyo, Amrih. 2005. Dua Jam Anda Tahu Cara Memastikan Air Yang Anda Minum Bukan Sumber Penyakit. Solo. Nomor seri e-buku 05-0000-100-0220 Distribusi Terbuka.

Peraturan Menteri Kesehatan Republik Indonesia

Tentang Persyaratan Kualitas Air Minum No 492/MENKES/PER/IV/2010

Nikmawati, Ellis E. 2007. Pentingnya Air dan Oksigen bagi Kesehatan Tubuh Manusia. Jakarta. Universitas Pendidikan Indonesia. Departemen Pekerjaan Umum Badan Penelitian Badan Penelitian Dan Pengembangan. 2004.

Penyediaan Air Bersih. Jakarta. Pusat Penelitian

Dan Pengembangan Sosial Ekonomi Budaya Dan Peran Masyarakat.

Warlina, Lina. 2004. Pencemaran Air: Sumber, Dampak Dan Penanggulangannya. Bogor. Makalah Pribadi, Istitut Pertanian Bogor.

Firdaus Yustisia Sembiring. 2008. Manajemen Pengawasan Sanitasi Lingkungan Dan Kualitas Bakteriologis Pada Depot Air Minum Isi Ulang kota Batam. Medan. Universitas Sumatera Utara.

Mariance, Rince. 2006. Karakteristik Fisis dan pH Sari Wortel. Bogor. Institut Pertanian Bogor. Skripsi.

Budianto, Anwar. 2008. Metode Penentuan Koefisisen Kekentalan Zat Cair Dengan Menggunakan Regresi Linear Hukum Stokes. Seminar Nasional SDM Teknologi Nuklir Yogyakarta, 25-26 Agustus 2008. ISSN 1978-0176.
Fitriyanto, dkk. 2013. Kajian Viskositas Dan Berat Jenis Susu Kambing Peranakan Etawa (Pe) Pada Awal, Puncak Dan Akhir Laktasi. Purwokerto. Fakultas Peternakan, Universitas Jendral Soedirman Purwokerto.

Sears dan Zemansky. 1999. Fisisa Universitas Edisi 10 Jilid 1. Jakarta. Erlangga.

Quality Assurance Departement. PT Ades Waters Indonesia Tbk.

Himati Ikfina dan Endarko. 2013. Pembuatan Elektroda dan Perancangan Sisitem Capacitive Deionization untuk mengurangi Kadar Garam Pada Larutansodium Clorida $(\mathrm{NaCl})$. Surabaya. Jurusan Fisisa, Fakultas MIPA, Institut Teknologi Sepuluh Nopember. Berkala Fisisa ISSN: $1410-$ 9662 Vol. 16, No. 3, Juli 2013, hal 67 - 74.

Yeni Dede. 2005. Studi Kasus Fisisa Pangan Pembuatan Tablet Effervescent Sari Buah Tomat. Bogor. Fakultas Matematika dan Ilmu Pengetahuan Alam, Institut Pertanian Bogor.

Rahma Siti. 2009. Pencitraan Dua Dimensi Data Resistivity Dan Induced Polarization Untuk Mendelineasi Deposit Emas Sistem Epithermal Di Daerah " $X$ ”. Jakarta. Fakultas Matematka Dan Ilmu Pengetahuan Alam, Univerrsitas Indonesia.

Suslow, T. 2004. Oxidation-Reduction Potensial (ORP) For Water Disinfection Monitoring, Control, and Dokumentation, ANR Publication 8149.

Putra Yulestra. 2004. Pengelolaan Limbah Rumah Tangga. Medan Program Studi Arsitektur Fakultas Teknik Universitas Sumatra Utara.

Purwanto dkk. 2004. Pengaruh Suhu Terhadap Konduktivitas Elektrolit Padat. Tangerang. Puslibang Iptek Bahan (P3IB)Batan. 